\title{
Sorption characteristic of starch-based film
}

\author{
1, ${ }^{*}$ Basha, R.K., ${ }^{1}$ Leong, K.Y., ${ }^{1}$ Othman, S.H., ${ }^{1}$ Talib, R.A., ${ }^{1}$ Naim, M.N., ${ }^{1}$ Hasnan, N.Z.N. \\ and ${ }^{1,2}$ Azmi, N.S. \\ ${ }^{1}$ Department of Process and Food Engineering, Faculty of Engineering, University Putra Malaysia, 43400 \\ Serdang, Selangor, Malaysia. \\ ${ }^{2}$ Department of Mechanical Engineering Technology, Faculty of Engineering Technology, University Tun \\ Hussein Onn Malaysia, 84600, Pagoh, Johor, Malaysia
}

\begin{abstract}
Article history:
Received: 16 July 2020

Received in revised form: 29

September 2020

Accepted: 31 January 2021

Available Online: 30 April 2021
\end{abstract}

\section{Keywords:}

Moisture sorption,

Starch-based film,

Isotherm model

DOI:

https://doi.org/10.26656/fr.2017.5(S1).056

\begin{abstract}
Moisture sorption characteristic is important in determining the stability of bio-based plastic during packaging and storage condition. This study was carried out to investigate the moisture sorption characteristic of starch-based film. Moisture sorption test was conducted at different temperatures $\left(5,30\right.$ and $\left.50^{\circ} \mathrm{C}\right)$ and relative humidity $(23-75 \%)$. The experimental data was fitted using several models. Based on the Peleg model, the maximum rate of absorption and absorption capacity occurred at higher relative humidity. Guggenheim Anderson de Boer (GAB) model was the most suitable model to fit the experimental isotherm data and it is useful to predict the water sorption properties of the film which relate to different relative humidity conditions. In addition, the shelf life of film was reduced when placed under lower temperature due to the higher sorption capacity of moisture. The sorption properties of the starch-based film are important and worth investigation as it will be useful for the final application in food packaging due to its dependency on this behaviour.
\end{abstract}

\section{Introduction}

Bio-based plastic derived from various plant resources such as starch and protein have been regarded as alternative materials to petroleum plastic because they are abundant, renewable and biodegradable (Liu et al., 2005; Koronis et al., 2013; Iwata, 2015; Gadhave et al., 2018). Packaging made from bio-based materials could help reduce greenhouse effect gas (GHG) emissions. The keys to success for the development of bio-based plastic are the performance should be improved to a level which is comparable with conventional plastic and the production cost should be reduced. However, in terms of cost and performance, the development of new materials from biomass is still lagging behind the conventional plastic.

Starch is one of the bio-based materials that has received much attention in the research of alternative biodegradable polymer. However, with high hydrophilic nature, starch tends to absorb moisture from surrounding and exhibit poor moisture barrier (Petersen et al., 1999; Yang and Paulson, 2000; Euaphantasate et al., 2008; Müller et al., 2009). Thus, the moisture content can significantly affect the physical and barrier properties of starch-based films (Euaphantasate et al., 2008). It was a big challenge to the manufacturing industry and consumer to maintain the physical and mechanical properties of the starch-based film during packaging and storage condition. Equilibrium properties and kinetics of water transport through packaging material are of great importance (Müller et al., 2009). It can be used to predict the stability and quality changes of plastic at different temperatures and relative humidity. In addition, understanding the relative importance of different mechanisms controlling moisture transfer through hygroscopic films is also important to design films with improved and selective barrier properties (Galus and Lenart, 2013).

Hence, with the growing awareness for the uses of moisture-sensitive bio-based films as food packaging, this study was carried out to investigate the moisture sorption characteristic by applying several isotherm models to predict the behaviour of starch-based film under varying relative humidity and temperature conditions. 


\section{Material and methods}

\subsection{Starch-based plastic}

The starch-based plastic samples were supplied by Maribumi Sdn Bhd. For the water sorption test, starchbased plastic was cut into a square dimension of $35 \times 35$ $\mathrm{mm}$ (Mali et al., 2005). The plastics were cut into a rectangular shape with a dimension of $100 \times 15 \mathrm{~mm}$ for determination of mechanical properties.

\subsection{Water sorption test}

Water sorption test was carried out using saturated salt solutions with different relative humidity. The samples were placed inside desiccators containing saturated salt solution and were placed inside an incubator to control the temperature. The experiment was carried out at temperatures of $5^{\circ} \mathrm{C}, 30^{\circ} \mathrm{C}$ and $50^{\circ} \mathrm{C}$. Saturated salt solutions in the separated desiccator gave storage environments at different relative humidity. Saturated salt solutions used in the experiment were potassium acetate $(23 \%)$, magnesium chloride $(33 \%)$, potassium carbonate $(43 \%)$, sodium bromide $(57 \%)$ and sodium chloride $(75 \%)$. Digital temperature and humidity meter was used to monitor the surrounding air moisture and temperature inside the desiccators.

\subsubsection{Determination of initial moisture content}

The initial weight of the samples was weighted using gravimetric weigher. The samples were cut into a square dimension of $35 \times 35 \mathrm{~mm}$ and pre-conditioned in a desiccator contained silica gel for 5 days to obtain the dry weight of the samples (Suppakul et al., 2013). The initial moisture content was calculated by using equation (1) (Hernandez, 1994):

$$
M_{i}=\frac{W_{i}-W_{d}}{w_{d}}
$$

Where, $M_{i}$ is an initial moisture content (\% dry basis), $W_{i}$ is an initial weight of the sample, (mg) and $W_{d}$ is a dry weight of the sample after pre-dried in the desiccator, (mg).

\subsubsection{Determination of equilibrium moisture content}

The samples were placed inside desiccators with different relative humidity at different temperature $\left(5^{\circ} \mathrm{C}\right.$, $30^{\circ} \mathrm{C}$ and $50^{\circ} \mathrm{C}$ ). The weight gained of each sample were determined using A digital weigher for the first 2, 5 and $8 \mathrm{hrs}$ to determine the sorption rate of film. After that, the weight of the film was measured periodically (every $24 \mathrm{hrs}$ ). Equilibrium moisture sorption was reached when the difference in weight between the two consecutive sample measurements was not greater than $1 \%$ (Mali et al., 2005). Samples were then dried in an oven at $105^{\circ} \mathrm{C}$ for $10 \mathrm{hrs}$ (De La Cruz et al., 2001). Equilibrium moisture content corresponding to different relative humidity was determined by using equation (2):

$$
M_{e}=\frac{W_{e}}{W_{i}}\left(M_{i}+1\right)-1
$$

Where, $M_{e}$ is an equilibrium moisture content of the sample (dry basis), (mg), $W_{i}$ is an initial weight of the sample, $(\mathrm{mg}), M_{i}$ is an initial moisture content of the product, (\% dry basis) and $W_{e}$ is an equilibrium weight of the sample, (mg).

\subsubsection{Determination of moisture adsorption kinetic}

The water absorption of starch-based plastic over a period of time was determined using the equation proposed by Peleg (1988):

$$
M_{t}=M_{i}+\frac{t}{K_{1}+K_{2} t}
$$

Where, $M_{t}$ is the moisture content at a known time, (\% dry basis), $M_{i}$ is initial moisture content, (\% dry basis), $t$ is the water absorption time, (in hour) and, $K_{l}$ and $K_{2}$ are Peleg constants. By rearranging the equation gives:

$$
\frac{t}{M_{t}-M_{i}}=K_{1}+K_{2} t
$$

Based on the plot of $\frac{t}{M_{t}-M_{i}}$ versus $t$, a straight line was obtained with $K_{1}$ as intercept value while $K_{2}$ is the gradient of the graph. The characteristic of Peleg's constant was determined from the plot.

\subsubsection{Fitting of experimental data to moisture sorption isotherm model}

Numerous isotherm models can be applied to determine the moisture sorption isotherm. The selected isotherm models used to fit in the experiment date were as follow:

i) GAB (Guggenheim Anderson de Boer) model

$$
\frac{M_{e}}{W_{m}}=\frac{C k a_{w}}{\left(1-K a_{w}\right)\left(1-K a_{w}+C a_{w}\right)}
$$

Where, $M_{e}$ is an equilibrium moisture content of the sample (dry basis), (mg), $W_{m}$ is a GAB monolayer moisture content, $\mathrm{C}$ is a Guggenheim constant, $\mathrm{a}_{\mathrm{w}}$ is a water activity, (\%) and $\mathrm{k}$ is a factor correcting properties of the multiplayer molecules corresponding to the bulk liquid. The parameters $\left(K, W_{m}\right.$ and $\left.\mathrm{C}\right)$ in GAB models were obtained from its second-order polynomial form:

$$
\begin{aligned}
& \frac{a_{w}}{M_{e}}=\alpha a_{\mathrm{ww}}{ }^{2}+\beta \mathrm{a}_{\mathrm{w}}+\gamma \\
& \text { Where: } \alpha=\frac{K}{W_{m}}\left(\frac{1}{c}-1\right), \quad \beta=\frac{1}{W_{m}}\left(1-\frac{2}{c}\right) \text { and } \gamma=\frac{1}{W_{m} K C}
\end{aligned}
$$

\section{ii) Smith model}

This model was normally used to describe the final curved portion of sorption isotherm of bioplastic with high molecular weight. The equation was expressed as 


$$
\mathrm{M}=\mathrm{A}-\mathrm{B} \log \left(1-\mathrm{a}_{\mathrm{w}}\right)
$$

Where the dimensionless constants A represents the moisture bound to the surface and $\mathrm{B}$ represent the moisture in a unimolecular layer of normally condensed moisture. The constant A and B were computed from intercept and slope of the linear regression of $M$ versus $\log \left(1-a_{w}\right)$.

iii) Halsey model

Halsey equation was established in 1948 and its equation was expressed as:

$$
\ln (\mathrm{M})=\mathrm{a}+\mathrm{b}\left(\ln \left(-\ln \left(\mathrm{a}_{\mathrm{w}}\right)\right)\right)
$$

Where $a$ and $b$ were the constants for equation. The Halsey constants were computed from a linear plot of $1 n$ (M) versus $\left.\ln \left(-\ln \left(a_{w}\right)\right)\right)$.

iv) Caurie model

The equation was expressed as

$$
\ln (\mathrm{M})=\ln \mathrm{A}-\mathrm{ra}_{\mathrm{w}}
$$

Where $\mathrm{A}$ and $\mathrm{r}$ were the constants for the equation. The constants were computed from a linear plot of $\ln (\mathrm{M})$ versus $a_{w}$.

v) Oswin model

The equation was expressed as

$$
\ln (\mathrm{M})=\ln \left(\mathrm{X}_{\mathrm{m}}\right)+\mathrm{n} \ln \left(\frac{\mathrm{a}_{\mathrm{w}}}{1-\mathrm{a}_{\mathrm{w}}}\right)
$$

Where $X_{m}$ and $n$ were the constants for the equation. The constants were computed from a linear plot of $\ln (\mathrm{M})$ versus $\ln \left(\frac{a_{w}}{1-a_{w}}\right)$

vi) Henderson model

Henderson equation was developed in 1970. It is a widely used model relating to relative humidity and the amount of moisture absorbed. The equation was expressed as:

$$
\ln (\mathrm{M})=\mathrm{n} \ln \left(-\ln \left(1-\mathrm{a}_{\mathrm{w}}\right)+\ln \mathrm{K}\right.
$$

Where $\mathrm{K}$ was constant of the equation.

\subsection{Mechanical test}

These mechanical properties indicate the mechanical performance of the materials. Tensile properties are most frequently considered, evaluated, and used throughout the industry. Tensile measurements for tensile strength, elongation at break and modulus of elasticity were performed with the universal testing machine system (Model 3365).

\section{Results and discussion}

\subsection{Moisture sorption characteristic}

The average initial moisture content was found to be $6.5 \%$. The value was measured to determine the equilibrium moisture content of the starch-based film after being placed inside desiccators under different relative humidity. The moisture adsorption for three different temperatures increased rapidly during the initial stage of 2 to $5 \mathrm{hrs}$. Low amount of moisture being adsorbed as time increased due to hydrophilic nature of the starch-based film which possessed high moisture sensitivity to absorb moisture from the surrounding (Chang et al., 2006; Basiak et al., 2017). The moisture content of the starch-based films reached a plateau indicating that they became equilibrated with the relative humidity of the storage (Mali et al., 2005). The moisture content of the film was influenced by the relative humidity of the storage. The result showed that the film stored at high relative humidity contained higher moisture compared to film stored at low relative humidity. In addition, the time needed for the film to achieve equilibrium state was also influenced by the relative humidity of the storage; the film which stored at the high relative humidity ( $75 \%$ ) took a long time to achieve equilibrium state compared to low relative humidity $(23 \%)$. These phenomena occurred due to highly gaps in moisture content between film and surrounding humidity where the moisture was transferred from high moisture content of the surrounding to the film with low moisture concentration. The continuous exchange of moisture where diffusion occurred from the air into the film, or the other way around was taking a long time to reach an equilibrium stage.

\subsection{Equilibrium moisture content of starch-based film}

Experimental result of equilibrium moisture content of starch-based film at different temperature was plotted in Figure 1. The equilibrium moisture content of starchbased film increased with the increase in relative humidity but decreased with an increase in temperature. This study showed that at the temperature of $5^{\circ} \mathrm{C}$, the increase of relative humidity from $23 \%$ to $75 \%$ resulted in an increment of $48.7 \%$ of moisture content. On the other hand, an increase in temperature from $5^{\circ} \mathrm{C}$ to $50^{\circ} \mathrm{C}$ caused a decrease of $15.1 \%$ equilibrium moisture content at a relative humidity of $23 \%$. Hence, it was found that both relative humidity and temperature had an effect on the equilibrium moisture content of the starch-based film. At high relative humidity, moisture content increased and caused the film to swell and open up new sites for water to bind which result in an increase in equilibrium moisture content (Chowdhury and Das, 2010, 2012). Mostafa and Sourell (2009) reported that the increased of equilibrium moisture content was due to 
the decrease of vapour pressure deficit (VPD) at high relative humidity thereby creating an atmosphere close to saturation and increased the ability of the film to absorb more moisture from the surrounding atmosphere. The decreased of equilibrium moisture content with increasing temperature might be due to the reduction of the total number of binding sites for water at high temperature which induced the changes in the microstructure of the starch film (Chowdhury and Das, 2012). According to Menkov et al. (2007), an increase of temperature will cause the water molecules in the film to become activated to a higher energy level, causing them to become less stable and break away from the water binding sites and thus decreased the equilibrium moisture content.

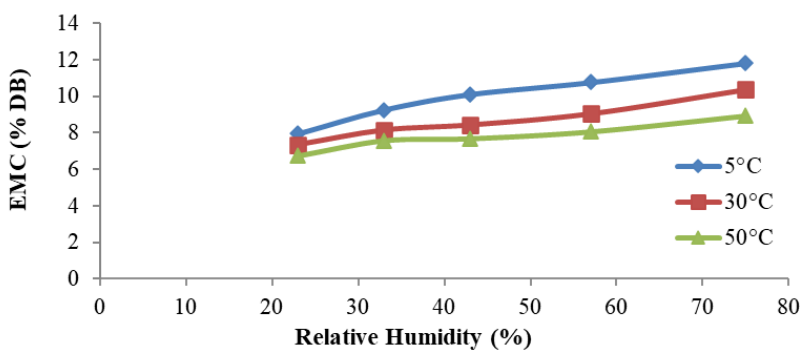

Figure 1. Equilibrium moisture content (EMC) of starchbased film at different temperature

\subsection{Moisture sorption kinetic of starch-based film using Peleg model}

In order to study the moisture sorption kinetic at different temperatures, sorption behaviour of starchbased film was fitted using Peleg Model. The characteristics of Peleg's constants were determined from plot of $t /\left(M_{t}-M_{i}\right)$ versus time, t. The $K_{1}, K_{2}$ and $R^{2}$ from curve fitting using Peleg. The models were tabulated in Table 1. Whereby, the constant of $K_{1}$ and $K_{2}$ represent the rate of sorption and capacity of sorption, respectively (Turhan et al., 2002).

The result showed that the values of $\mathrm{K}_{1}$ and $\mathrm{K}_{2}$ decreased as $\mathrm{RH}$ was increased indicating that water sorption rate and sorption capacity increased with an increase in relative humidity. There was similar observation for the decreasing values of $\mathrm{K}_{1}$ and $\mathrm{K}_{2}$ as relative humidity increased at three different temperatures. $\mathrm{K}_{1}$ is the rate of sorption of film. The low value of $\mathrm{K}_{1}$ indicated that film absorbed faster and more rapidly at high relative humidity. A low value of $\mathrm{K}_{2}$ was observed as relative humidity increased indicating maximum absorption capacity of the film. Temperature effect on sorption rate can be observed at $50^{\circ} \mathrm{C}$ and $5^{\circ} \mathrm{C}$, whereby the value of $\mathrm{K}_{1} 50^{\circ} \mathrm{C}$ is $21.87 \%$ lower than $\mathrm{K}_{1}$ at $5^{\circ} \mathrm{C}$. This indicates high sorption rate at high storage temperature of the film. The high sorption rate was due to water transfer which was promoted at high temperatures (Hizaji et al., 2010). In this study the coefficient of regression, $\mathrm{R}^{2}$ varied from 0.98 to 0.99 indicating that Peleg Model was well fitted to the experimental data for the investigation of water absorption of starch-based film at different relative humidity.

\subsection{Fitting of experimental data (equilibrium moisture content) to various moisture sorption isotherm model}

Moisture sorption isotherm models are generally used to describe the relationship between the moisture content of a material and equilibrium relative humidity at a given temperature over a range of moisture levels (Ganesan et al., 2008). Moisture sorption isotherm can be effectively used to evaluate the effect of temperature and relative humidity on the sample properties (Cadden, 1988; Lai and Padua, 1998). Six moisture sorption isotherm models were used in this study. The stability of these models to fit the experimental data of equilibrium moisture content under different relative humidity at a given temperature was evaluated by referring to $R^{2}$ value. They are important and useful in judicious selection of water vapour barrier packaging film. The sorption constants of the different model are important in the evaluation of stability and shelf life of film at different temperature (Raj et al., 2003).

The GAB model applied to the sorption studies of starch-based film. The result of constants for GAB model, which were $\mathrm{W}_{\mathrm{m}}, \mathrm{K}$ and $\mathrm{C}$ were computed from non-linear regression of $a_{w} / M_{e}$ versus $a_{w}$ and were tabulated in Table 2. The experimental data were well fitted for the range of water activity with $\mathrm{R}^{2}, 0.99$ indicating that GAB model was in agreement with the experimental result of water sorption of starch-based film.

Table 1. Comparison of linear regression, constant $\mathrm{K}_{1}, \mathrm{~K}_{2}$ and coefficient of regression, $\mathrm{R}^{2}$ from curve fitting using Peleg Model at different temperature

\begin{tabular}{cccccccccc}
\hline \multirow{2}{*}{$\mathrm{RH}(\%)$} & \multicolumn{3}{c}{$5^{\circ} \mathrm{C}$} & \multicolumn{3}{c}{$30^{\circ} \mathrm{C}$} & \multicolumn{3}{c}{$50^{\circ} \mathrm{C}$} \\
\cline { 2 - 10 } & $\mathrm{K}_{1}$ & $\mathrm{~K}_{2}$ & $\mathrm{R}^{2}$ & $\mathrm{~K}_{1}$ & $\mathrm{~K}_{2}$ & $\mathrm{R}^{2}$ & $\mathrm{~K}_{1}$ & $\mathrm{~K}_{2}$ & $\mathrm{R}^{2}$ \\
\hline 23 & 0.636 & 0.295 & 0.982 & 0.617 & 0.311 & 0.979 & 0.575 & 0.616 & 0.995 \\
33 & 0.597 & 0.208 & 0.99 & 0.596 & 0.196 & 0.996 & 0.552 & 0.261 & 0.998 \\
43 & 0.542 & 0.215 & 0.996 & 0.575 & 0.192 & 0.997 & 0.523 & 0.288 & 0.997 \\
57 & 0.44 & 0.134 & 0.991 & 0.438 & 0.172 & 0.988 & 0.377 & 0.196 & 0.988 \\
75 & 0.262 & 0.108 & 0.998 & 0.312 & 0.111 & 0.990 & 0.215 & 0.155 & 0.997 \\
\hline
\end{tabular}


Table 2. Comparison of various fitting isotherm model

\begin{tabular}{|c|c|c|c|c|}
\hline \multirow{2}{*}{ Model } & \multirow{2}{*}{ Constant } & \multicolumn{3}{|c|}{ Temperature $\left({ }^{\circ} \mathrm{C}\right)$} \\
\hline & & 5 & 30 & 50 \\
\hline \multirow{6}{*}{ GAB } & $\mathrm{W}_{\mathrm{m}}$ & 0.12 & 0.07 & 0.07 \\
\hline & $\mathrm{C}$ & 48.43 & 572.31 & 190.52 \\
\hline & $\mathrm{K}$ & 0.16 & 0.46 & 0.33 \\
\hline & $\mathrm{R}^{2}$ & 0.99 & 0.99 & 0.99 \\
\hline & RMSE (\%) & 0.83 & 1.59 & 2.08 \\
\hline & $\mathrm{P}(\%)$ & 0.78 & 1.31 & 1.64 \\
\hline \multirow{5}{*}{ Smith } & $\mathrm{A}$ & 7.82 & 6.94 & 6.61 \\
\hline & $\mathrm{B}$ & 3.11 & 2.50 & 1.73 \\
\hline & $\mathrm{R}^{2}$ & 0.88 & 0.98 & 0.92 \\
\hline & RMSE (\%) & 5.01 & 1.93 & 2.78 \\
\hline & $\mathrm{P}(\%)$ & 4.34 & 1.48 & 2.11 \\
\hline \multirow{5}{*}{ Halsey } & $\mathrm{A}$ & 2.22 & 2.09 & 2.00 \\
\hline & $\mathrm{b}$ & -0.23 & -0.20 & -0.16 \\
\hline & $\mathrm{R}^{2}$ & 0.9 & 0.98 & 0.93 \\
\hline & RMSE (\%) & 4.33 & 1.51 & 2.42 \\
\hline & $\mathrm{P}(\%)$ & 4.00 & 1.19 & 1.92 \\
\hline \multirow{5}{*}{ Caurie } & $\mathrm{A}$ & 7.10 & 6.47 & 6.21 \\
\hline & $\mathrm{R}$ & -0.72 & -0.62 & -0.49 \\
\hline & $\mathrm{R}^{2}$ & 0.93 & 0.98 & 0.94 \\
\hline & RMSE (\%) & 3.59 & 1.62 & 2.28 \\
\hline & $\mathrm{P}(\%)$ & 3.22 & 1.35 & 1.76 \\
\hline \multirow{5}{*}{ Oswin } & $\mathrm{Xm}$ & 7.10 & 6.47 & 6.21 \\
\hline & $\mathrm{N}$ & 0.16 & 0.14 & 0.11 \\
\hline & $\mathrm{R}^{2}$ & 0.94 & 0.97 & 0.95 \\
\hline & RMSE (\%) & 3.31 & 1.29 & 1.69 \\
\hline & $\mathrm{P}(\%)$ & 3.06 & 1.13 & 1.54 \\
\hline \multirow{5}{*}{ Henderson } & $\mathrm{K}$ & 7.10 & 6.47 & 6.21 \\
\hline & $\mathrm{N}$ & 0.23 & 0.20 & 0.16 \\
\hline & $\mathrm{R}^{2}$ & 0.97 & 0.98 & 0.96 \\
\hline & RMSE (\%) & 2.44 & 1.65 & 1.90 \\
\hline & $\mathrm{P}(\%)$ & 2.15 & 1.45 & 1.60 \\
\hline
\end{tabular}

The Smith constants, A and B were computed from the intercept and slope of the linear regression of $\mathrm{M}$ versus $-\ln \left(1-a_{w}\right)$ line. Smith model was found to fit the experimental data well at $30^{\circ} \mathrm{C}$ whereby the coefficient of regression, $\mathrm{R}^{2}$ was 0.98 . For $5^{\circ} \mathrm{C}$ and $50^{\circ} \mathrm{C}$, Smith model showed less acceptable performance in fitting the experimental data where the $\mathrm{R}^{2}$ of the temperatures were 0.88 and 0.92 , respectively.

The Halsey model constants were estimated from a linear plot of $\ln \mathrm{M}$ versus $\ln \left(-\ln \left(\mathrm{a}_{\mathrm{w}}\right)\right)$. The constants $a$ and $b$ as tabulated in Table 2 were computed from the intercept and slope of linear regression. A similar observation of Hasley model has been showed for the experimental data at $30^{\circ} \mathrm{C}$ with the coefficient of regression, $\mathrm{R}^{2}$ was 0.98 . For $5^{\circ} \mathrm{C}$ and $50^{\circ} \mathrm{C}$, Halsey model also showed less acceptable performance in the experimental data fitting where the $\mathrm{R}^{2}$ of the temperatures were 0.90 and 0.93 respectively, consistent with the Smith model.
The Caurie model fitted the sorption experimental data of starch-based film from a linear plot of $\ln (\mathrm{M})$ versus $a_{w}$. Caurie model did not fit well with experimental data at the temperature of $5^{\circ} \mathrm{C}$ and $50^{\circ} \mathrm{C}$ whereby the $\mathrm{R}^{2}$ of both temperatures were 0.93 and 0.94 , respectively. The Caurie model was only well fitted to the sorption experimental data at $30^{\circ} \mathrm{C}$ whereby the $\mathrm{R}^{2}$ was 0.98 .

The Henderson model constants, $\mathrm{K}$ and $\mathrm{n}$ were computed from a linear plot of $\ln (\mathrm{M})$ versus $\ln (-\ln (1$ $\left.a_{w}\right)$ ). The constants were determined by a linear fitting of sorption isotherm. The Henderson model was well fitted to sorption experiment data where $\mathrm{a}_{\mathrm{w}}$ range from 0.2 to 0.8 whereby the coefficient of regression, $\mathrm{R}^{2}$ varied within the range of 0.96 to 0.98 for three different temperatures.

Oswin model was based on mathematical series expansion for sigmoidal curves (Raj et al., 2003). The model constants, $X_{m}$ and $n$ were determined by the linear regression of $\ln X_{m}$ versus $\ln \left(a_{w}\left(1-a_{w}\right)\right)$. Table 2 shows that the experimental sorption data of the starch-based film applied to Oswin model was well fitted at the temperature of $30^{\circ} \mathrm{C}$ and the performance of the model was less applicable for $5^{\circ} \mathrm{C}$ and $50^{\circ} \mathrm{C}$ where the $\mathrm{R}^{2}$ for both temperatures were 0.94 and 0.95 respectively.

The suitability of each model was determined by comparison of relative percentage deviation $(\mathrm{P} \%)$ and percentage of root mean square error (RMSE) (Lomauro et al., 1985). The model is considered suitable if the value of $\mathrm{P}$ is less than $10 \%$. The model is considered acceptable if RMSE which is the difference between experimental and predicted moisture content is less than $10 \%$. Equation (12) and (13) were RMSE and P respectively.

$$
\begin{aligned}
& \text { RMSE }=\left(\frac{\left.\sum \text { (Experimental value }- \text { predicted } \text { value }^{2}\right)}{\mathrm{N}}\right)^{1 / 2} \\
& \mathrm{P}(\%)=\frac{100}{N}\left(\frac{\text { Experimental value-predicted value }}{\text { Experimental value }}\right)
\end{aligned}
$$

Where $\mathrm{N}$ is the number of observations.

Table 2 shows that the value of RMSE (\%) and P (\%) for all the isotherm models were less than $10 \%$ indicating an acceptable performance in describing the experimental data. The best model selected was the GAB model because it showed higher adequacy of fitting between experimental and predicted data in the relative humidity range from $23-75 \%$. In addition, the GAB model was well fitted with the highest value of the coefficient of regression, $\mathrm{R}^{2}$ which is 0.99 for three different temperature. The value of RMSE and P for the GAB model was lower compared to other isotherm models. Therefore, the best model selected was one based on the highest value of $\mathrm{R}^{2}$ and the least error 
values (RMSE and $\mathrm{P})$.

The constant of the GAB model was used to analyze the moisture sorption characteristic of the starch-based film. Table 2 shows that films which stored at $5^{\circ} \mathrm{C}$ presented the highest monolayer value, $\mathrm{W}_{\mathrm{m}}(0.1203 \mathrm{mg}$ moisture $/ \mathrm{mg}$ solid) compared to the film stored at $30^{\circ} \mathrm{C}$ (0.06811 mg moisture $/ \mathrm{mg}$ solid) and $50^{\circ} \mathrm{C}(0.06818 \mathrm{mg}$ water $/ \mathrm{mg}$ solid). The monolayer value indicated the maximum amount of moisture absorbed in a single layer per milligram of the dry film (Strauss et al., 1991). It can be stated that the starch film which placed under lower temperature absorbed more moisture compared to films which placed under higher temperature. The result was supported by the Peleg model with the lowest value of $\mathrm{K}_{2}$ at $5^{\circ} \mathrm{C}$ with $75 \% \mathrm{RH}$ indicating the maximum sorption capacity. While parameter $\mathrm{C}$ is the difference of magnitude in the upper layer and the monolayer (Timmermann et al., 2001) and $\mathrm{K}$ is independent of the $\mathrm{C}$ value. (Coupland et al., 2000). If constant $\mathrm{C}$ is larger than 2, the GAB model should yield a sigmoidal shape with the point of inflexion while $\mathrm{K}$ provides a measure of interactions between molecules in multilayer with the adsorbent and tends to fall between the energy values of the molecules in the monolayer and that of liquid water. The prescribed range for $\mathrm{K}$ values is $0<\mathrm{K}<1$. As can be observed in Table 2, the value of $\mathrm{K}$ at different temperatures was within the range. The value of $\mathrm{C}$ was greater than 2 and the isotherm curve showed sigmoidal, thus supporting the prediction. Therefore, the GAB model provided a better prediction of moisture sorption properties for the starch-based film from water activity range from 0.2 to 0.8 and it can be used to predict the storage stability of the starch-based film. Based on the constant, $\mathrm{W}_{\mathrm{m}}$ which is the sorption capacity, it can be predicted that the shelf life of starch-based film is reduced when it is placed under lower temperature conditions. The higher sorption capacity occurred in the film stored at lower temperature with increasing the deterioration rate of the film.

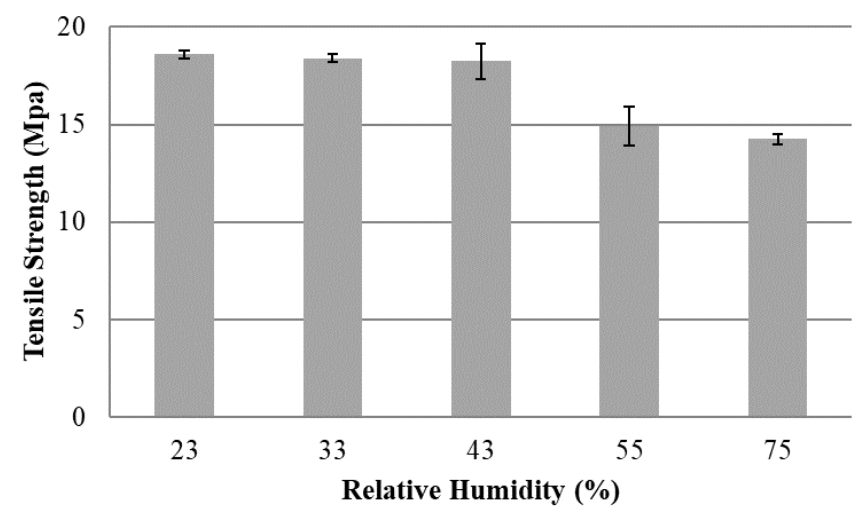

Figure 2. Tensile strength of starch-based film after conditioning at $30^{\circ} \mathrm{C}$ and different relative humidity.

\subsection{Mechanical properties}

Figures 2 and 3 show the tensile strength and elongation at break of starch film conditioning at various relative humidity respectively. After conditioning at $30^{\circ}$ $\mathrm{C}$ for 1 week, it was found that tensile strength and elongation at break decreased with the increase of relative humidity. Due to its inherent hydrophilic nature, starch tends to absorb large quantities of moisture at elevated relative humidity conditions. The moisture content can significantly affect the physical properties of starch-based film (Euaphantasate et al., 2008).

\section{Conclusion}

The water sorption test indicates that a higher equilibrium moisture content was required for the film which stored at higher relative humidity. While the equilibrium moisture content decreased as increasing temperature. Based on the Peleg model, the maximum rate of absorption and absorption capacity occurred at higher relative humidity. Guggenheim Anderson de Boer (GAB) model was the most suitable model to fit the experimental isotherm data and it was useful in predicting the water sorption properties of the film which relate to different relative humidity condition. From the model, it can be predicted the shelf life of film was reduced when placed under lower temperature due to the higher sorption capacity of moisture which increased the rate of deterioration of film. Due to the property of starch, which is hydrophilic in nature, the equilibrium moisture content plays an important role in starch-based plastic manufacturing. During storage and distribution, the final moisture of plastic will be determined by temperature and relative humidity surrounding the plastic. Proper handling of starch-based plastic during storage is important to reduce the deterioration rate of starch-based plastic in high relative humidity. The result from this study provided information on the effect of temperature on the water sorption of starch-based plastic under different relative humidity which will be helpful for further reference and improvement of starch-based

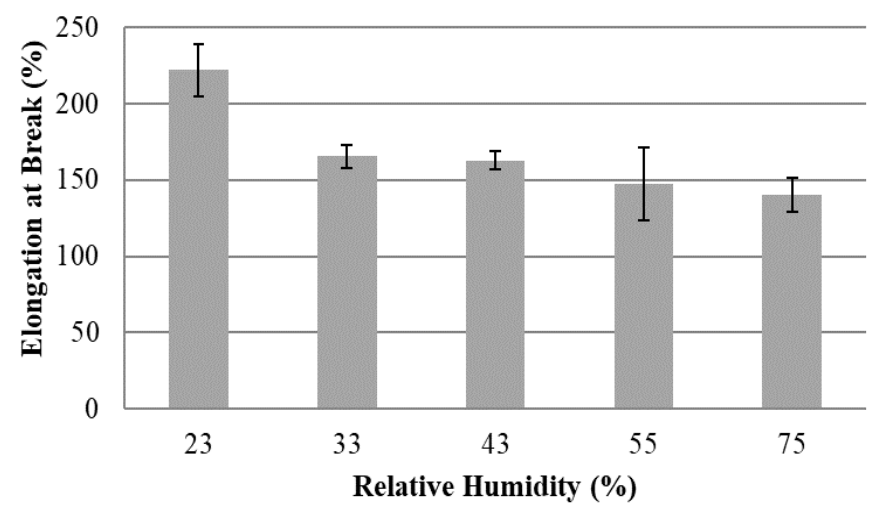

Figure 3. Elongation at break of starch-based film after conditioning at $30^{\circ} \mathrm{C}$ and different relative humidity. 
plastic manufacturing industries.

\section{Acknowledgments}

The authors acknowledge Universiti Putra Malaysia for providing financial support for the research project (GP/2017/9547500).

\section{References}

Basiak, E., Lenart, A. and Debeaufort, F. (2017). Effect of starch type on the physico-chemical properties of edible films. International Journal of Biological Macromolecules, 98, 348-356. https:// doi.org/10.1016/j.ijbiomac.2017.01.122

Cadden, A.-M. (1988). Moisture Sorption Characteristics of Several Food Fibers. Journal of Food Science, 53 (4), 1150-1155. https://doi.org/10.1111/j.13652621.1988.tb13550.x

Chang, Y.P., Abd Karim, A. and Seow, C.C. (2006). Interactive plasticizing-antiplasticizing effects of water and glycerol on the tensile properties of tapioca starch films. Food Hydrocolloids, 20(1), 1-8. https://doi.org/10.1016/j.foodhyd.2005.02.004

Chowdhury, T. and Das, M. (2010). Moisture sorption isotherm and isosteric heat of sorption characteristics of starch based edible films containing antimicrobial preservative. International Food Research Journal, 17(3), 601-614.

Chowdhury, T. and Das, M. (2012). Moisture sorption isotherm and isosteric heat of sorption of edible films made from blends of starch, amylose and methyl cellulose. International Food Research Journal, 19(4), 1669-1678.

Coupland, J.N., Shaw, N.B., Monahan, F.J., Dolores O'Riordan, E. and O'Sullivan, M. (2000). Modeling the effect of glycerol on the moisture sorption behavior of whey protein edible films. Journal of Food Engineering, 43(1), 25-30. https:// doi.org/10.1016/S0260-8774(99)00129-6

De La Cruz, G.V., Torres, J.A. and Martín-Polo, M.O. (2001). Temperature effect on the moisture sorption isotherms for methylcellulose and ethylcellulose films. Journal of Food Engineering, 48(1), 91-94. https://doi.org/10.1016/S0260-8774(00)00143-6

Euaphantasate, N., Prachayawasin, P., Uasopom, S. and Methacanon, P. (2008). Moisture Sorption Characteristic and their Relative Properties of Thermoplastic Starch/Linear Low Density Polyethylene Films for Food Packaging. Journal of Metals, Materials and Minerals, 18, 103-109.

Gadhave, R.V., Das, A., Mahanwar, P.A. and Gadekar, P.T. (2018). Starch Based Bio-Plastics: The Future of Sustainable Packaging. Open Journal of Polymer Chemistry, 8(2), 21-33. https://doi.org/10.4236/ ojpchem.2018.82003

Galus, S. and Lenart, A. (2013). Development and characterization of composite edible films based on sodium alginate and pectin. Journal of Food Engineering, 115(4), 459-465. https:// doi.org/10.1016/j.jfoodeng.2012.03.006

Ganesan, V., Muthukumarappan, K. and Rosentrater, K.A. (2008). Sorption isotherm characteristics of Distillers Dried Grains with Solubles (DDGS). Transactions of the ASABE, 51(1), 169-176. https:// doi.org/10.13031/2013.24201

Hernandez, R.J. (1994). Effect of water vapor on the transport properties of oxygen through polyamide packaging materials. Journal of Food Engineering, 22(1-4), 495-507. https://doi.org/10.1016/02608774(94)90050-7

Hizaji, A.S., Maghsoudlou, Y. and Jafari, S.M. (2010). Application of peleg model to study effect of water temperature and storage time on rehydration kinetics of air dried potato cubes. Latin American Applied Research, 40(2), 131-136.

Iwata, T. (2015). Biodegradable and bio-based polymers: Future prospects of eco-friendly plastics. Angewandte Chemie - International Edition, 54(11), 3210-3215. https://doi.org/10.1002/anie.201410770

Koronis, G., Silva, A. and Fontul, M. (2013). Green composites: A review of adequate materials for automotive applications. Composites Part B: Engineering, 44(1), 120-127. https:// doi.org/10.1016/j.compositesb.2012.07.004

Lai, H.M. and Padua, G.W. (1998). Water vapor barrier properties of zein films plasticized with oleic acid. Cereal Chemistry, 75(2), 194-199. https:// doi.org/10.1094/CCHEM.1998.75.2.194

Liu, W., Misra, M., Askeland, P., Drzal, L.T. and Mohanty, A.K. (2005). "Green" composites from soy based plastic and pineapple leaf fiber: Fabrication and properties evaluation. Polymer, 46 (8), 2710-2721. https://doi.org/10.1016/ j.polymer.2005.01.027

Lomauro, C.J., Bakshi, A.S. and Labuza, T.P. (1985). Evaluation of food moisture sorption isotherm equations part I: Fruit, vegetable and meat products. LWT - Food Science and Technology, 18(2), 111117.

Mali, S., Sakanaka, L.S., Yamashita, F. and Grossmann, M.V.E. (2005). Water sorption and mechanical properties of cassava starch films and their relation to plasticizing effect. Carbohydrate Polymers, 60(3), 283-289. https://doi.org/10.1016/ 
j.carbpol.2005.01.003

Menkov, N.D., Durakova, A.G. and Krasteva, A. (2007).

Moisture Sorption Isotherms of Sesame Flour at Several Temperatures. Food Technology. Biotechnology, 45(1), 96-100. https:// doi.org/10.1080/13102818.2004.10817145

Mostafa, H.M. and Sourell, H. (2009). Equilibrium Moisture Content of Some Bioplastic Materials for Agricultural Use. Agricultural Engineering International: CIGR Journal, 11, 1-10.

Müller, C.M.O., Laurindo, J.B. and Yamashita, F. (2009). Effect of cellulose fibers addition on the mechanical properties and water vapor barrier of starch-based films. Food Hydrocolloids, 23(5), 1328 -1333 . https://doi.org/10.1016/ j.foodhyd.2008.09.002

Peleg, M. (1988). An Empirical Model for the Prediction. Journal of Food Science, 53(4), 12161217. https://doi.org/10.1111/j.13652621.1988.tb13565.x

Petersen, K., Væggemose Nielsen, P., Bertelsen, G., Lawther, M., Olsen, M.B., Nilsson, N.H. and Mortensen, G. (1999). Potential of biobased materials for food packaging. Trends in Food Science and Technology, 10(2), 52-68. https:// doi.org/10.1016/S0924-2244(99)00019-9

Raj, B., Raj, A.E., Madan, P. and Siddaramaiah. (2003). Modeling of moisture sorption isotherms of poly (vinyl alcohol)/starch films. Journal of Applied Polymer Science, 89(14), 3874-3881. https:// doi.org/10.1002/app.12589

Strauss, U.P., Porcja, R.J. and Chen, Y. (1991). Volume effects of starch water interactions. In Levine, $\mathrm{H}$. and Slade, L. (Eds.), Water Relationships in Foods, p. 351-363. New York: Plenum Press. https:// doi.org/10.1007/978-1-4899-0664-9_20

Suppakul, P., Chalernsook, B., Ratisuthawat, B., Prapasitthi, S. and Munchukangwan, N. (2013). Empirical modeling of moisture sorption characteristics and mechanical and barrier properties of cassava flour film and their relation to plasticizing -antiplasticizing effects. LWT - Food Science and Technology, 50(1), 290-297. https://doi.org/10.1016/ j.lwt.2012.05.013

Timmermann, E.O., Chirife, J. and Iglesias, H.A. (2001). Water sorption isotherms of foods and foodstuffs: BET or GAB parameters? Journal of Food Engineering, 48(1), 19-31. https://doi.org/10.1016/ S0260-8774(00)00139-4

Turhan, M., Sayar, S. and Gunasekaran, S. (2002). Application of Peleg model to study water absorption in chickpea during soaking. Journal of
Food Engineering, 53(2), 153-159. https:// doi.org/10.1016/S0260-8774(01)00152-2

Yang, L. and Paulson, A.T. (2000). Mechanical and water vapour barrier properties of edible gellan films. Food Research International, 33(7), 563-570. https://doi.org/10.1016/S0963-9969(00)00092-2 